\title{
Un estudio de las estrategias de asignación de valor de aminoácidos a las fitasas
}

\section{A study of the strategies of amino acid value assignment to phytases}

\author{
María Alejandra Pérez Alvaradoa, Diego Alfredo Calderón Montañeza, \\ Diego Braña Varelaa,b, J osé Antonio Cuarón I bargüengoytiaa,b
}

\begin{abstract}
RESUMEN
Se evaluó el comportamiento productivo de cerdos sometidos a una reducción de aminoácidos en la dieta. Durante 63 días, con un total de 96 cerdos en dos bloques y con peso inicial promedio de $42.7 \pm 4.58 \mathrm{~kg}$, se estudiaron seis tratamientos producto de un arreglo factorial $2 \times 3$ ( 2 dietas, $C P=$ dieta convencional y $\mathrm{CN}=$ dieta reducida en aminoácidos) y (3 equipares de fitasa: 0, sin fitasa; Fitasa A y Fitasa B). Semanalmente se registró el consumo de alimento; los cerdos se pesaron en intervalos de 21 días y se midió la profundidad de grasa y del músculo largo dorsal con un ultrasonido de tiempo real al inicio y final del ensayo; en los días 10, 31 y 52 del experimento, se determinó además la concentración plasmática de nitrógeno de urea. No hubo efectos en ninguna de las variables productivas $(P>0.15)$, excepto en la eficiencia alimenticia acumulada a los 63 días $(P<0.08)$, donde los tratamientos con fitasa fueron superiores. En la utilización de nutrientes, sólo hubo efecto de la dieta para lisina digestible $(\mathrm{P}<\mathbf{0 . 0 3})$, pero las concentraciones plasmáticas de nitrógeno de urea fueron las mismas $(P<0.18)$. En conclusión, reducir la concentración de aminoácidos en dietas para cerdos desde los 40 kg de peso corporal, no afecta el comportamiento productivo por su capacidad para compensar diferencias en la densidad de nutrientes por el consumo; así el uso de fitasas debe proyectarse por la liberación de $\mathbf{P}$ y de energía.
\end{abstract}

PALABRAS CLAVE: Cerdos, Crecimiento, Comportamiento productivo, Fitasa, Aminoácidos.

\begin{abstract}
The objective of this study was to evaluate the productive performance of growing pigs fed reduced amino acids diets by the use of phytase. During $63 \mathrm{~d}$ (three $21 \mathrm{~d}$ feeding phases), a total of 96 pigs in two blocks (consecutive farrowing groups), of an average initial weight of $42.7 \pm 4.58 \mathrm{~kg}$, were randomized to six treatments which consisted of a $2 \times 3$ factorial arrangement (conventional diet, a positive control= CP or reduced in amino acids by the addition of phytase, a negative control= CN) and ( 3 leads of phytase: 0 , Phytase A or Phytase B). Weekly feed intake was recorded. At start and the end of each feeding-phase pigs were weighed and fat and muscle depths were measured using real time ultrasound. At the end of each feeding phase, blood samples were drawn to determine plasma urea nitrogen. Aside for final feed efficiency, which was slightly improved by phytase $(P<0.08)$, there were no significant effects on any of the dependent variables during the $63 \mathrm{~d}$ trial $(P>0.15)$. On the efficiency of utilization of nutrients, there was an obvious effect by level of digestible lysine $(P<0.03)$, better in the lower lysine diets, although plasma urea nitrogen levels were the same for all treatments $(P<0.18)$. In conclusion, a slight reduction in the concentration of amino acids, nor the addition of phytase to diets for pigs from $\mathbf{4 0} \mathrm{kg}$ of body weight affect productive performance due to the inherent variation of the apportion and of the requirements.
\end{abstract}

KEY WORDS: Pigs, Growth, Productive performance, Phytase, Amino acids.

La razón primaria del uso de fitasas exógenas en los alimentos para animales es hidrolizar los
The primary reason for the use of exogenous phytase in animal feed is to hydrolyze phytates,

Recibido el 24 de septiembre de 2014. Aceptado el 6 de marzo de 2015

a Programa de Maestría y Doctorado en Ciencias de la Producción y la Salud Animal, Facultad de Estudios Superiores - Cuautitlán, UNAM. México. palvaradoa@hotmail.com.

b Centro Nacional de Investigación Disciplinaria en Fisiología y Mejoramiento Animal, INIFAP. México. 
fitatos, con lo que se logra la liberación de nutrientes, particularmente del fósforo, calcio y zinc quelados(1,2). Por un efecto asociativo, la digestibilidad de otros elementos, se ve también beneficiada y se logra mejorar la digestión de la energía $(2,3,4)$ y de los aminoácidos $(5,6)$. En la producción de cerdos, el incremento en el aprovechamiento del fósforo es suficiente para justificar el uso de las fitasas y el impacto en la disponibilidad de energía es de consideración( 2,4$)$, mientras que, en el caso de los aminoácidos, los beneficios son cuestionables $(7,8,9)$ porque la magnitud de mejoría en los coeficientes de digestibilidad es relativamente pequeña y muy variable(10), dependiendo del ingrediente, de la dieta y del aminoácido de que se trate $(11,12,13)$.

En consecuencia, antes de proyectar ventajas por las mejoras en la digestibilidad de los aminoácidos, es necesario ponderar la variación. Por ejemplo, el incremento promedio en la digestibilidad ileal verdadera o estandarizada de todos los aminoácidos esenciales por efecto de fitasa, puede estar en el orden de 3.5 unidades porcentuales $(12,14,15)$, pero el coeficiente de variación (CV) de la digestibilidad inherente llegar a más del $30 \%$ (12). En la práctica, no se pondera la variación por la potencial liberación de aminoácidos a la acción de las fitasas y normalmente se asignan valores matriciales, lo que equivale a una reducción fija de la demanda $y$, por lo tanto, del aporte de nutrientes por los ingredientes, que redunda en un ahorro en el costo de las dietas. Esto supone un aporte teórico de aminoácidos, que bien puede descomponer el necesario balance entre los limitantes, pero las consecuencias son de menor importancia, porque la variación del requerimiento es mayor que aquélla inducida por el ajuste en la concentración en la dieta y por el "aporte" de las fitasas. Por ejemplo, el $\mathrm{CV}$ del requerimiento de lisina puede ser cercano al $20 \%(13)$, mientras que la reducción por el uso de la fitasa seguramente será menor al $5 \%(6,13,14)$. Adicionalmente, las dietas típicamente exceden los requerimientos promedio de la población(15), quizá hasta en which releases nutrients, particularly the phosphorus, zinc and calcium chelates $(1,2)$; by an associative effect, energy $(2,3,4)$ and $(5,6)$ amino acids digestibility is also improved. In pig production, increased phosphorus utilization is sufficient to justify the phytase dietary addition, but the impact on energy availability is of consideration $(2,4)$, while, in the case of amino acids, the benefits are questionable $(7,8,9)$ because the magnitude of improvement in digestibility coefficients is relatively small and highly variable(10), depending on diet ingredients, and factorially, on the amino acid in question $(11,12,13)$.

Consequently, to account for possible improvements on the amino acids digestibility by phytase, it is necessary to ponder variation. As an example, the average increase in true or standardized ileal digestibility of the essential amino acids could be in the order of 3.5 percentage units $(12,14,15)$, but the coefficient of variation (CV) of the inherent digestibility may reach more than $30 \%(12)$. In practice, the potential release of amino acids variation is not weighted to the action of the phytase and normally fixed Matrix values are assigned to a reduction of the requirement. Therefore, the relaxation of nutrients supply from the ingredients may result in savings, but this theoretical contribution of amino acids may well break the necessary balance, although this may be of minor consequences, because the requirements variation is greater than the changes induced by the setting of values "contributed" by the phytase. For instance, the $\mathrm{CV}$ of the lysine requirement may be close to $20 \%(13)$, while the reduction induced by the application of a phytase will surely be less than $5 \%(6,13,14)$. Additionally, diets typically exceed the average requirements of the population(15), perhaps by $10 \%$. Therefore, the content of amino acids in the diet may be reduced by the inherent variation and lower magnitude of the expected effect of the enzyme, but it is necessary to recognize that the projection of a value of amino acids for phytase, can safely reduce the dietary protein levels, to lower diet 
un $10 \%$. Por lo tanto, bien podría reducirse el contenido de aminoácidos en la dieta, por la variación inherente a los requerimientos, y por la menor magnitud del efecto esperado de la enzima. Así, la proyección de un valor de aminoácidos para fitasa, puede ser una forma segura de reducir los niveles de proteína en las dietas, con lo que se podrán mejorar los precios de los alimentos y quizá proteger el rendimiento de energía neta (EN), pero para aprovechar esto, es necesario asegurar que no se incurra en deficiencias.

Este trabajo, partió de la hipótesis de que la reducción de aminoácidos en la dieta de cerdos en crecimiento es posible, independientemente del valor de aminoácidos que se presuman liberados por la fitasa, sin que se altere el comportamiento productivo de los animales.

El trabajo se realizó en la granja de cerdos del Centro Nacional de Investigación Disciplinaria en Fisiología y Mejoramiento Animal, INIFAP, situado en Ajuchitán, municipio de Colón, Querétaro, México, a $20^{\circ} 41^{\prime} 42.09^{\prime \prime} \mathrm{N}, 100^{\circ}$ $00^{\prime} 55.93^{\prime \prime} \mathrm{O}$ y a $1,969 \mathrm{msnm}$. La temperatura promedio durante el experimento fue de 20.5 ${ }^{\circ} \mathrm{C}$ con una mínima y máxima registradas de 6.0 y $34.2{ }^{\circ} \mathrm{C}$ respectivamente y $43.47 \%$ de humedad relativa promedio.

El experimento se condujo durante 63 días, con un total de 96 cerdos (hembras y machos castrados) producto de un cruzamiento GP8 $x$ Fertilis 25 (Genetiporc, México) y con un peso inicial de $42.7 \pm 4.58 \mathrm{~kg}$, en dos bloques, que fueron grupos consecutivos de producción en intervalos de 28 días. Los animales se alojaron en corraletas individuales desde 14 días previos al inicio del experimento, período que se consideró de aclimatación para estandarizar las prácticas de alimentación y de manejo. Las corraletas están en un edificio tipo frente abierto, sin control de temperatura y con ventilación natural; cada corraleta tuvo una superficie efectiva de $1.2 \mathrm{~m}^{2}$, con $30 \%$ de piso con malla trenzada de acero y el resto de piso sólido de concreto, un comedero de tolva y un bebedero de chupón opuesto al comedero. costs and perhaps to protect net energy yield. However, to take advantage of this, it is necessary to ensure not to incur in deficiencies.

The work presented herein, parts from the hypothesis that the reduction of amino acids in the diet of growing pigs is possible, without altering growth performance, regardless of the amino acids value assigned to the phytase.

The experiment was conducted at the National Center of Disciplinary Research in Animal Physiology, INIFAP, pig farm located in Ajuchitlán, Colón Municipality, Querétaro State, Mexico at $20^{\circ} 41^{\prime} 42.09^{\prime \prime} \mathrm{N}, 100^{\circ} 00^{\prime} 55.93^{\prime \prime} \mathrm{W}$, and at $1,969 \mathrm{~m}$ asl. The average temperature during the experiment was $20.5{ }^{\circ} \mathrm{C}$, with a minimum and maximum registered of 6.0 and $21.3{ }^{\circ} \mathrm{C}$ respectively and $43.47 \%$ average relative humidity.

In two blocks (consecutive farrowing groups), a total of 96 pigs (half gilts and barrows), product of a commercial breeding program (GP8 sires $x$ Fertilis 25 dams, Genetipoc, Mexico), were used at an average initial weight of $42.7 \pm 4.58 \mathrm{~kg}$. Prior the start of the experiment, the animals were housed individually from an acclimation period of $14 \mathrm{~d}$, where the trial was conducted during $63 \mathrm{~d}$; the individual pens are in an open front building, with natural ventilation and no environmental control aside from roofing. Each pen provided an effective surface of $1.2 \mathrm{~m}^{2}$, with solid concrete and $30 \%$ steel braided mesh flooring; each pen was equipped with a hopper feeder and a nipple watering device opposite to the feeder.

To stablish the dietary treatments, first a sample of the different phytases nutrients matrixes in the Mexican market $(n=11)$ was made, selecting two commercial products, one which showed values close to the average (Phytase A), and one with the largest declared release of amino acids (Phytase B). Treatments (6), resulted from a factorial arrangement $(2 \times 3)$, where two diets, (1) a positive Control (CP), which consisted of a conventional diet (no phytase added) and (2) 
Para el desarrollo de los tratamientos, se partió de un muestreo de las matrices de diferentes fitasas en el mercado mexicano $(n=11)$, donde se seleccionó la que mostró un valor lo más cercano al promedio (Fitasa A) y aquélla con la mayor equivalencia de liberación de aminoácidos (Fitasa B). Los tratamientos (6), resultaron de un arreglo factorial $(2 \times 3)$, donde se partió de dos dietas que fueron un control positivo (CP), que consistió en una dieta convencional en la que no se incluyó fitasa, y una dieta control negativo $(\mathrm{CN})$, en la que se redujeron los aminoácidos en función de un supuesto de liberación por las fitasas (Cuadro 1), y tres niveles o equipares por la adición o no de las fitasas: 1) CP, 0 (sin fitasa); 2) $C P$ + Fitasa $A$; 3) $\mathrm{CP}+$ Fitasa $\mathrm{B}$; 4) $\mathrm{CN}, 0$ (sin fitasa); 5) $\mathrm{CN}$ + Fitasa $A$; 6) $C N$ + Fitasa $B$.

El experimento siguió un programa de alimentación en tres fases, cada una de 21 días, en el que la formulación de las dietas se realizó mediante programación lineal a costo mínimo. La energía neta (EN) se fijó en $2.5 \mathrm{Mcal} / \mathrm{kg}$, partiendo de los valores de los ingredientes, como se calcularon con las ecuaciones apropiadas(16); con este nivel de EN se buscó evitar un efecto confundido por la liberación de energía por las fitasas(17). Los niveles de lisina digestible (ileal estandarizada, Lysd) en el CP, para cada fase de alimentación, fueron los validados previamente para la población y correspondientes a los calculados con las rutinas del NRC(18); en relación a Lysd, se mantuvo un perfil de proteína ideal calculado por la divergencia entre el mantenimiento y la demanda para síntesis de proteína muscular(18), cuidando las relaciones con Thr, Trp y Met, hasta el quinto aminoácido limitante (Ile/Val). Para el cálculo de las dietas del CN, simplemente se relajó la restricción en la densidad de aminoácidos del CP conforme a la proyección de liberación redondeada a la décima superior de la propuesta de aporte más alta (reducción aplicada, Cuadro 1). En todas las dietas, los niveles de $\mathrm{Ca}, \mathrm{P}$ y de $\mathrm{P}$ disponible (Pd) para cada una de las fases de alimentación, se ajustaron por el uso de fitasa para resultar en a negative Control (NC), in which amino acids levels were reduced by the addition of phytase according to the so-called liberation of amino acids (Table 1), and three levels or leads of phytase: 0 (no phytase added), Phytase $A$ and Phytase B. Thus the array of the 6 dietary treatments was: 1) CP, 0 (without phytase); 2) $\mathrm{CP}$ + Phytase A; 3) CP + Phytase B; 4) CN, 0 (without phytase); 5) $\mathrm{CN}+$ Phytase $A$ and 6) $\mathrm{CN}+$ Phytase B.

The experiment followed a three phases feeding program, each of $21 \mathrm{~d}$, in which the diets formulation was by means of linear programming at minimum cost. Net energy (NE) was set at $2.5 \mathrm{Mcal} / \mathrm{kg}$, based on the values of the ingredients, as they were calculated with the appropriate equations(16); this level of NE was set to prevent confounded effects by the release of energy by phytase(17). Digestible lysine levels (ileal standardized, Lysd) in the CP, for each phase of feeding was validated previously for the population used, and values were similar to the calculated with the routines of the NRC(18); in relation to Lysd, Thr, Trp, Met, until the fifth limiting amino acid (Ile/Val) ratios were kept to an ideal protein profile,

Cuadro 1. Reducción de la densidad de aminoácidos en las dietas con la propuesta de dos fitasas comerciales y la proyección usada (\%)

Table 1. Reduction of the dietary amino acids densities as proposed by two commercial phytases and the applied projection (\%)

\begin{tabular}{lccc}
\hline $\begin{array}{l}\text { Amino } \\
\text { acid }\end{array}$ & $\begin{array}{c}\text { Contribution } \\
\text { of Phytase A }\end{array}$ & $\begin{array}{c}\text { Contribution } \\
\text { of Phytase B }\end{array}$ & $\begin{array}{c}\text { Applied } \\
\text { projectiona }\end{array}$ \\
\hline Lys & 0.012 & 0.026 & 0.030 \\
Met & 0.004 & 0.006 & 0.010 \\
Cys & 0.003 & 0.051 & 0.060 \\
Thr & 0.007 & 0.049 & 0.050 \\
Trp & 0.002 & 0.028 & 0.030 \\
Val & 0.011 & 0.034 & 0.040 \\
lle & 0.012 & 0.038 & 0.040 \\
\hline
\end{tabular}

a The reduction of amino acids was rounded to the superior tenth of the observed higher proposed contribution. 
una reducción de $\mathrm{Pd}$ del 29 al $48 \%$ del requerimiento(19), con la finalidad de que el $\mathrm{Pd}$ en el CN (sin fitasas) no impidiera la máxima expresión del crecimiento $(20,21)$; en todos los casos, se cuidó que la relación Ca:P fuera la misma, i.e., Ca:P en el rango $>1.00<1.15$.

En el Cuadro 2, se detallan los ingredientes de las dietas y su análisis calculado; todos los alimentos se fabricaron en pellet con un tamaño de $4 \mathrm{~mm}$. A manera de constatación, se analizaron los contenidos de materia seca (MS), proteína cruda (PC), calcio (Ca) y fósforo (P) conforme a los procedimientos de la AOAC(22). La alimentación fue a libertad dividida en dos comidas diarias (8000 y 1800 h) y los cerdos se pesaron al inicio y cada 21 días para estimar la ganancia diaria de peso (GDP). Diariamente se registró el alimento ofrecido y al final de cada semana se pesaron los remanentes en los comederos, para calcular el consumo diario de alimento (CDA) y la eficiencia alimenticia como la ganancia de peso en función del consumo $(\mathrm{G} / \mathrm{C})$.

Para estimar la composición corporal(23), al inicio y al final del experimento se realizaron mediciones de profundidad de la grasa dorsal y del músculo largo dorsal a la altura de la 10a y última costillas, sobre el punto 2 (P2) ubicado a $6.5 \mathrm{~cm}$ de la línea media, con un equipo de ultrasonido en tiempo real ALOKA SSD-500 (Aloka Co. Ltd.) usando un transductor lineal de $17.5 \mathrm{~cm}$ y $3.5 \mathrm{MHz}$.

Se calculó la eficiencia de uso de la EM, EN y Lysd, como la ganancia diaria de peso (GDP) en función del consumo de cada uno de estos nutrientes: Eficiencia de EM, g/Mcal= GDP, g / (CDA, $g \times$ EM en la dieta, Mcal); Eficiencia de EN, g/Mcal= GDP, g / (CDA, $g \times E N$ en la dieta, Mcal); Eficiencia de Lysd, $g=$ GDP, $\mathrm{g} /$ (CDA, $\mathrm{g} \times$ Lysd en la dieta, $\mathrm{g}$ ).

Diez días después de iniciada cada una de las fases de alimentación, los cerdos se sometieron a un ayuno de 7 a $8 \mathrm{~h}$, al retirar el alimento $2 \mathrm{~h}$ después de la comida de la mañana, para calculated by the divergence between the maintenance and demand for synthesis of muscle protein(18). For the calculation of the $\mathrm{CN}$ diets, simply the restriction of amino acids density of the CP was relaxed to the projection of rounded release, to the tenth higher, by phytase (applied reduction, Table 1). In all diets, levels of $\mathrm{Ca}, \mathrm{P}$ and available $\mathrm{P}(\mathrm{Pd})$ for each of the feeding phases, was adjusted by the use of phytase, to result in a reduction of $\mathrm{Pd}$ from 29 to $48 \%$ of the requirement(19), with the aim that Pd in the CN (without phytase) was sufficient for the maximum expression of growth $(20,21)$; in all cases, the Ca: $P$ ratio was the same, i. e., Ca:P in the range $>1.0$ or < 1.15.

In Table 2, feed ingredients are listed and dietary calculated analyses are depicted; all diets were produced to $4 \mathrm{~mm}$ pellets and dry matter (DM), crude protein (PC), calcium (Ca) and phosphorus $(\mathrm{P})$ were analyzed in accordance with the procedures of the $A O A C(22)$ to verify diets composition prior feeding. Feeding was to satiety in 2 daily meals ( 8000 and 1800 h), daily offerings were recorded and orts measured at the end of each week, to calculate daily feed intake (ADF). Pigs' body weight was logged at the start of the experiment and in $21 \mathrm{~d}$ intervals to assess average of daily weight gain (ADG). Feed efficiency was calculated as the gain to feed ratio (GXF).

To estimate body composition(23), at the beginning and at the end of the experiment pigs were measured for back fat and and Longissimus dorsi depths, at the 10th and last ribs, on P2 using a real-time ultrasound equipment ALOKA SSD-500 (Aloka Co. Ltd.), using a linear $17.5 \mathrm{~mm}$ and 3.5 MHz transducer.

Efficiency of ME, NE and Lysd use was estimated as ADG as a function of the daily intake of each of these nutrients: ME efficiency, $\mathrm{g} / \mathrm{Mcal}=\mathrm{ADG}, \mathrm{g} /(\mathrm{ADF}, \mathrm{g} \times$ dietary ME , Mcal); NE efficiency, g/Mcal= ADG, g / (ADF, $g \times$ dietary NE, Mcal); Lysd efficiency, $g=$ ADG, $g$ / (ADF, $g \times$ dietary Lysd, $g$ ). 
Cuadro 2. Composición y análisis de las dietas*

Table 2. Diets composition and analysis*

\begin{tabular}{|c|c|c|c|c|c|c|}
\hline & \multicolumn{2}{|c|}{ Feeding phase 1} & \multicolumn{2}{|c|}{ Feeding phase 2} & \multicolumn{2}{|c|}{ Feeding phase 3} \\
\hline & $\mathrm{CP}$ & $\mathrm{CN}$ & $\mathrm{CP}$ & $\mathrm{CN}$ & $\mathrm{CP}$ & $\mathrm{CN}$ \\
\hline \multicolumn{7}{|l|}{ Ingredient, $\mathrm{kg} \cdot \mathrm{t}^{-1}$} \\
\hline Sorghum, grain & 365.885 & 392.560 & 382.125 & 399.045 & 419.855 & 436.848 \\
\hline Maize, grain & 340.000 & 340.000 & 380.000 & 397.000 & 418.000 & 436.000 \\
\hline Soy bean meal & 134.000 & 111.400 & 96.000 & 82.000 & 64.000 & 50.000 \\
\hline Canola, meal & 100.000 & 100.000 & 96.000 & 82.000 & 65.000 & 50.000 \\
\hline Tallow, choice & 32.000 & 28.000 & 22.000 & 16.000 & 9.000 & 3.000 \\
\hline Limestone & 7.400 & 7.500 & 7.330 & 7.290 & 7.300 & 7.240 \\
\hline Benzoic acid a & 4.000 & 4.000 & 3.000 & 3.000 & 2.000 & 2.000 \\
\hline Mono-di Ca phosphate & 3.900 & 4.000 & 1.300 & 1.500 & 1.700 & 1.800 \\
\hline L-Lysine·HCl & 3.830 & 4.030 & 3.650 & 3.920 & 4.190 & 4.474 \\
\hline Salt & 3.600 & 3.600 & 3.600 & 3.600 & 3.600 & 3.600 \\
\hline Vitamins, premix b & 2.200 & 2.200 & 2.000 & 2.000 & 2.000 & 2.000 \\
\hline L-Threonine & 1.300 & 1.100 & 1.330 & 1.130 & 1.600 & 1.400 \\
\hline Minerals, premix c & 0.900 & 0.900 & 0.800 & 0.800 & 0.800 & 0.800 \\
\hline MicroSource d & 0.500 & 0.500 & 0.500 & 0.500 & 0.500 & 0.500 \\
\hline L-Tryptophan & 0.285 & 0.000 & 0.225 & 0.015 & 0.255 & 0.048 \\
\hline DL-Methionine & 0.200 & 0.210 & 0.140 & 0.200 & 0.200 & 0.290 \\
\hline Sum & 1,000 & 1,000 & 1,000 & 1,000 & 1,000 & 1,000 \\
\hline Relative cost, \% & 100 & 94.12 & 100 & 94.42 & 100 & 94.00 \\
\hline \multicolumn{7}{|l|}{ Calculated analysis } \\
\hline $\mathrm{ME}, \mathrm{Mcal} / \mathrm{kg}$ & 3.312 & 3.289 & 3.282 & 3.261 & 3.246 & 3.226 \\
\hline $\mathrm{NE}, \mathrm{Mcal} / \mathrm{kg}$ & 2.500 & 2.500 & 2.500 & 2.500 & 2.500 & 2.500 \\
\hline Protein $(\mathrm{N} \times 6.25), \% \mathrm{e}$ & 16.27 & 15.36 & 14.45 & 13.51 & 12.50 & 11.54 \\
\hline Lys, \% & 1.07 & 1.02 & 0.94 & 0.90 & 0.84 & 0.80 \\
\hline Digestible Lys, \% & 0.90 & 0.87 & 0.80 & 0.77 & 0.73 & 0.70 \\
\hline Digestible Thr, \% & 0.60 & 0.55 & 0.54 & 0.49 & 0.50 & 0.45 \\
\hline $\mathrm{Ca}, \%$ e & 0.47 & 0.47 & 0.42 & 0.41 & 0.40 & 0.38 \\
\hline$P, \%$ e & 0.42 & 0.42 & 0.37 & 0.36 & 0.35 & 0.33 \\
\hline$P$ available(18), \% & 0.15 & 0.15 & 0.10 & 0.10 & 0.10 & 0.10 \\
\hline
\end{tabular}

* Enzymes were added or no by adjusting grain sorghum, at $0.200 \mathrm{~kg} \cdot \mathrm{t}^{-1}$.

$\mathrm{CP}=$ Positive control; $\mathrm{CN}=$ Negative control.

a VevoVitall ${ }^{\circledR}$, DSM Nutritional Products México.

b Vitamin premix contributed the following concentrations per $\mathrm{kg}$ : Vitamin A, 4,250 Ul. $\mathrm{g}^{-1}$; Vitamin $\mathrm{D}_{3}, 800 \mathrm{UI} \cdot \mathrm{g}^{-1}$; Vitamin E, 32 Ul. $\mathrm{g}^{-1}$; Menadione, $1.5 \mathrm{~g} \cdot \mathrm{kg}^{-1}$; Biotin, $120 \mathrm{~g} \cdot \mathrm{kg}^{-1}$; Cyanocobalamin, $16 \mathrm{~g} \cdot \mathrm{kg}^{-1}$; Choline, $250 \mathrm{~g} \cdot \mathrm{kg}^{-1}$; Folic acid, $800 \mathrm{~g} \cdot \mathrm{kg}^{-1}$; Niacin, $15 \mathrm{~g} \cdot \mathrm{kg}^{-1}$; Pantothenic acid, $13 \mathrm{~g} \cdot \mathrm{kg}^{-1}$; Pyridoxine, $2.5 \mathrm{~g} \cdot \mathrm{kg}^{-1}$; Riboflavin $5 \mathrm{~g} \cdot \mathrm{kg}^{-1}$; Thiamin, $1.25 \mathrm{~g} \cdot \mathrm{kg}^{-1}$.

c Trace minerals premix contributed the following amounts per kg: Co, $0.60 \mathrm{mg}$; Cu, $14 \mathrm{mg}$; Fe, $100 \mathrm{mg}$; I, $0.80 \mathrm{mg}$; Mn, $40 \mathrm{mg}$; Se, $0.25 \mathrm{mg} ; \mathrm{Zn}, 120 \mathrm{mg}$.

d MicroSource ${ }^{\circledR}$ viable spores of three specific strains, two of Bacillus subtillis and one of Bacillus lichenformis. DSM Nutritional Products México.

e Analyzed composition. 
sangrar por punción de la vena cava anterior, con aguja calibre 21G, conectada a tubos de 10 $\mathrm{ml}$ con heparina de litio pulverizada (BD Vacutainer ${ }^{\circledR}$, México), a fin de separar el plasma, en el que se determinó el nitrógeno de urea usando un kit reactivo (RandoxLabs ${ }^{\circledR}$, Reino Unido) con un analizador automático (Selectra Junior, Vital Scientific Dieren, Países Bajos).

El análisis estadístico de los datos se condujo como un diseño de bloques completos al azar, siendo los bloques los dos grupos de producción usados; se distinguieron los efectos mayores del sexo, de la dieta (CP o CN), de fitasa (0, A o B) y sus posibles interacciones. Los cálculos se facilitaron con los procedimientos GLM y MIXED (respuestas repetidas en el tiempo), del paquete estadístico SAS (v.9.2) y las variables dependientes se presentan como las medias de mínimos cuadrados de la respuesta acumulada a los 63 días del período experimental, salvo el $\mathrm{N}$ de urea en plasma que se ponderó al tiempo.

La reducción en el contenido de aminoácidos, como se proyectó con los valores en el Cuadro 1, resultó en una reducción del costo relativo de los alimentos CN equivalente al $5.82 \%$ del CP en el promedio de las tres fases de alimentación (Cuadro 2), consecuencia de la reducción en la concentración de las pastas de oleaginosas, particularmente de soya, y ligeros ajustes de los aminoácidos cristalinos, con lo que se pudo mantener relativamente constante la relación entre los aminoácidos limitantes.

Al analizar las respuestas en el tiempo, las tendencias de comportamiento fueron paralelas $(P>0.43)$, mientras que los efectos del sexo fueron los obvios y resultado de los patrones de consumo y maduración de los tejidos $(24,25)$. En ninguno de los casos se encontraron cualquiera de las posibles interacciones ( $P>0.17$, por lo que, los resultados se presentan en los Cuadros 3 y 4, como las medias de mínimos cuadrados de las respuestas acumuladas al final del período experimental, mostrando los efectos mayores del sexo, cuando ocurrieron, al pie de los mismos cuadros. Con
Ten days after each feeding phase start, pigs were fasted during 7 to $8 \mathrm{~h}$ (feed removed 2 $\mathrm{h}$ after the morning meal), to bleed by puncture of the vena cava using $21 \mathrm{G}$ needle gauge, connected to $10 \mathrm{ml}$ sprayed lithium heparin tubes (BD Vacutainer ${ }^{\circledR}$, Mexico), in order to separate the plasma for urea nitrogen determination with a reagent kit (RandoxLabs ${ }^{\circledR}$, United Kingdom) and an automatic Analyzer (Selectra Junior, Vital Scientific Dieren, Netherlands).

Data were statistically analyzed as a randomized complete block design, being blocks the two production groups used. Major effects of sex, diet (CP or $\mathrm{CN})$, phytase $(0, \mathrm{~A}$ or $\mathrm{B})$ and their possible interaction were separated; calculations were eased by means of the procedures MIXED (responses in time time) and GLM of SAS (v.9.2); dependent variables are presented as the least squares of the response accumulated to the $63 \mathrm{~d}$ of the experimental period, except for plasma urea $\mathrm{N}$ that was weighted in time.

Reduction in amino acid content, as it was projected with the values in Table 1, resulted in a reduction of the relative cost of the $\mathrm{CN}$ diets, which was equivalent in the average of the three-phase feed to a $5.82 \%$ of the CP price (Table 2), mostly in consequence of the reduced oil seeds meals, particularly soybeans, and to a lesser extent by the adjustments of crystalline amino acids to maintain relatively constant the relationships to Lysd.

Analyzing the responses in time, treatments trends were of a parallel pattern $(P>0.43)$, while the effects of sex were the obvious and result of feed intake and tissues maturation $(24,25)$. In none of the cases were found any of the possible interactions ( $P>0.17$ ) thus, results are presented in Tables 3 and 4, as the least squares means of the accumulated responses at the end of the experimental period. The sex effects, when they occurred, are depicted as foot notes in the same tables. With the $\mathrm{N}$ blood plasma urea, there were no effects of time, treatments or their interaction 
el $\mathrm{N}$ urea en plasma sanguíneo, no se encontraron efectos del tiempo, de los tratamientos o su interacción ( $P>0.19$ ), por lo que las medias en el Cuadro 4 corresponden a los tres períodos de muestreo.

No se encontraron diferencias en los parámetros productivos entre tratamientos para la respuesta acumulada a 63 días ( $P>0.10)$, por lo que, independientemente del esquema de formulación, o del valor de liberación de aminoácidos que se asigne a las fitasas, no se alterará la respuesta productiva (Cuadro 3). Se encontró un efecto de la dieta (CN vs CP) en la eficiencia de uso de la Lysd consumida $(\mathrm{P}<0.03)$, consecuencia directa de la densidad del nutriente en los alimentos, pero la adición de cualquiera de las fitasas no indujo una mejoría detectable ( $P>0.24)$. Sin embargo, el nitrógeno de urea en plasma, como un indicador de los requerimientos y eficiencia de uso de los aminoácidos, no mostró diferencias para los efectos de la dieta, del tiempo (fase de alimentación) o de fitasa ( $P>0.18)$.
$(P>0.19)$, thus least squares means in Table 4 correspond to the average of the three sampling periods.

Regardless of the scheme of feed formulation, or the hypothetical value for amino acids released by the phytases, there were no differences in productive parameters among treatments, for any of the responses accumulated to $63 \mathrm{~d}(\mathrm{P}>0.10)$, hence the suggested value of amino acids for the phytases or a slight reduction in amino acids dietary densities are of no consequences in the pigs' productive response (Table 3 ). There was a clear (obvious) diet effect (CN vs CP) in the efficiency of Lysd use $(P<0.03)$, a direct consequence of the density of the nutrient in feed, but the addition of any of the phytases did not induce a detectable improvement $(P>0.24)$. Conversely, urea nitrogen in plasma, as an indicator of the requirements or metabolization of the amino acids, showed no differences for the effects of diet, time (feeding phase) or phytase ( $P>0.18)$.

Cuadro 3. Comportamiento productivo de cerdos, alimentados con dos dietas, una convencional (control positivo) y una reducida en aminoácidos (control negativo), adicionadas o no con dos fitasasa

Table 3. Productive performance of pigs fed conventional (positive control) or lower amino acids (negative control) diets, added or not with two phytasesa

\begin{tabular}{|c|c|c|c|c|c|c|c|c|c|}
\hline \multirow[b]{2}{*}{$\begin{array}{l}\text { Phytase } A, \mathrm{~kg} \cdot \mathrm{t}^{-1} \\
\text { Phytase } \mathrm{B}, \mathrm{kg} \cdot \mathrm{t}^{-1} \\
\end{array}$} & \multicolumn{3}{|c|}{ Positive control } & \multicolumn{3}{|c|}{ Negative control } & \multirow[b]{2}{*}{ SEM } & \multicolumn{2}{|c|}{$P<$} \\
\hline & $\begin{array}{l}0 \\
0\end{array}$ & $\begin{array}{c}0.2 \\
0\end{array}$ & $\begin{array}{c}0 \\
0.2\end{array}$ & $\begin{array}{l}0 \\
0\end{array}$ & $\begin{array}{c}0.2 \\
0\end{array}$ & $\begin{array}{c}0 \\
0.2\end{array}$ & & Diet & Phytase \\
\hline Initial weight, kg & 41.50 & 42.42 & 43.22 & 43.31 & 43.30 & 42.41 & 0.986 & 0.44 & 0.88 \\
\hline Feed intake, $\mathrm{kg} \cdot \mathrm{d}^{-1} \mathrm{~b}$ & 2.30 & 2.19 & 2.18 & 2.34 & 2.23 & 2.22 & 0.068 & 0.40 & 0.12 \\
\hline Body weight gain, $\mathrm{kg} \cdot \mathrm{d}^{-1} \mathrm{c}$ & 0.99 & 1.01 & 0.95 & 1.02 & 1.00 & 1.00 & 0.029 & 0.39 & 0.53 \\
\hline Feed efficiency (G/F) d,e & 0.43 & 0.47 & 0.44 & 0.44 & 0.46 & 0.45 & 0.011 & 0.91 & 0.08 \\
\hline Loin muscle depth, cm & 4.64 & 4.53 & 4.54 & 4.74 & 4.68 & 4.56 & 0.103 & 0.28 & 0.37 \\
\hline Backfat depth, $\mathrm{cm}{ }^{f}$ & 1.33 & 1.29 & 1.34 & 1.39 & 1.36 & 1.26 & 0.062 & 0.71 & 0.64 \\
\hline Fat-free lean gain, $\mathrm{kg} \cdot \mathrm{d}^{-1}$ & 0.37 & 0.35 & 0.34 & 0.36 & 0.37 & 0.36 & 0.012 & 0.22 & 0.43 \\
\hline
\end{tabular}

$\mathrm{SEM}=$ Standard error of the mean. $\mathrm{n}=96$ pigs.

a Cumulative response to $63 \mathrm{~d}$, least squares means.

b Sex effect $(P<0.001)$ : gilts, 2.09 vs barrows, $2.39 \mathrm{~kg} \cdot \mathrm{d}^{-1}, \mathrm{SEM}=0.0374$.

c Sex effect $(P<0.005)$ : gilts, 0.96 vs barrows, $1.03 \mathrm{~kg} \cdot \mathrm{d}^{-1}, \mathrm{SEM}=0.0168$.

d Sex effect $(P<0.002)$ : gilts, 0.46 vs barrows, $0.43 \mathrm{~kg}$, SEM $=0.0063$.

e Phytase effect $(P<0.08)$; phytase added diets resulted in better feed efficiency $(A, 0.46 ; B, 0.45 \mathrm{~kg})$ than phytase void diets $(0.43 \mathrm{~kg})$; SEM= 0.0080 .

f Sex effect $(P<0.001)$ : gilts, 1.21 vs barrows, $1.45 \mathrm{~cm}, \mathrm{SEM}=0.0351$. 
Cuadro 4. Eficiencia calculada del uso de energía y lisina para la ganancia de peso y nitrógeno de urea en plasma, en respuesta a la densidad de aminoácidos corregida por fitasa*

Table 4. Calculated efficiency of energy and lysine use for the body weight gain and plasma urea nitrogen, in response to dietary amino acids density, corrected or not by phytase application*

\begin{tabular}{|c|c|c|c|c|c|c|c|c|c|}
\hline \multirow[b]{2}{*}{ Phytase A, $\mathrm{kg} \cdot \mathrm{t}^{-1}$} & \multicolumn{3}{|c|}{ Positive control } & \multicolumn{3}{|c|}{ Negative control } & \multirow{3}{*}{ SEM } & \multicolumn{2}{|c|}{$P<$} \\
\hline & 0 & 0.2 & 0 & 0 & 0.2 & 0 & & Diet & Phytase \\
\hline Phytase $\mathrm{B}, \mathrm{kg} \cdot \mathrm{t}^{-1}$ & 0 & 0 & 0.2 & 0 & 0 & 0.2 & & & tivguse \\
\hline ME efficiency, $g \cdot M c a l-1$ a & 140.40 & 150.77 & 145.76 & 146.57 & 148.41 & 148.02 & 3.7078 & 0.50 & 0.26 \\
\hline NE efficiency, $g \cdot M^{\prime} a l^{-1} b$ & 184.26 & 197.88 & 191.33 & 191.15 & 193.51 & 193.02 & 4.8683 & 0.73 & 0.26 \\
\hline Digest. Lys efficiency, $g \cdot g^{-1} c, d$ & 57.05 & 61.22 & 59.13 & 61.37 & 62.25 & 62.04 & 1.4873 & 0.03 & 0.24 \\
\hline Plasma urea $\mathrm{N}, \mathrm{mg} \cdot \mathrm{dL}^{-1} \mathrm{e}$ & 7.25 & 5.93 & 6.12 & 6.19 & 5.56 & 6.18 & 0.5206 & 0.34 & 0.24 \\
\hline
\end{tabular}

* Least squares means.

$\mathrm{SEM}=$ Standard error of the mean; $\mathrm{n}=96$ pigs.

a Sex effect $(P<0.06)$ : gilts, 149.57 vs barrows, $143.73 \mathrm{Mcal} \cdot \mathrm{g}^{-1}$. SEM= 2.1171 .

b Sex effect $\left(P<0.05\right.$; gilts, 195.68 vs barrows, $188.04 \mathrm{Mcal} \cdot \mathrm{g}^{-1}, \mathrm{SEM}=2.7797$.

c Sex effect $(P<0.05$; gilts, 61.74 vs barrows, $59.29 \mathrm{~g}$. SEM $=0.8493$.

d Diet effect $(P<0.03)$ : CN, 61.89 vs CP, 59.14 g. SEM= 0.8595.

e Average of three measurements ( $\mathrm{d} 10,31$ and 52 of the experiment). Sex effect $(P<0.02)$ : gilts, 5.60 vs barrows, 6.82 mg.dL-1, EEM= 0.2973 ).

Una reducción moderada en el contenido de aminoácidos de la dieta (propiamente de proteína excedente) no afecta el comportamiento productivo de los cerdos durante su crecimiento, y podría resultar en menores consumos $(\approx 10 \%)$, sin que se altere la eficiencia alimenticia, de uso de la lisina o de la energía; como puede corroborarse por la identidad con las concentraciones de $\mathrm{N}$ de urea en sangre, entre tratamientos y en el tiempo.

En conclusión, se puede optimizar la rentabilidad relajando ligeramente la concentración de aminoácidos en las dietas, como se mostró en este caso con cerdos desde los $40 \mathrm{~kg}$ de peso corporal, por ejemplo, al eliminar factores de seguridad innecesarios en la formulación y descansando en la enorme variación del consumo voluntario de alimento. La asignación de valores de aminoácidos a las fitasas con una matriz de factorización, puede confundir la formulación y posiblemente inducir a pérdidas de precisión en la satisfacción puntual de los requerimientos. En suma: la liberación de nutrientes por la acción de enzimas exógenas no resulta en aumentos de la productividad de
A moderate reduction in the content of amino acids in the diet (by itself of excess protein) does not affect productive performance of growing pigs and may result in lower intake $(\approx 10 \%)$, not altering the feed, lysine or energy efficiency of utilization; as it is could also be suggested by the identity of plasma urea $\mathrm{N}$ within treatments and time.

In conclusion, profitability can be optimized by slightly relaxing the concentration of amino acids in diets, as shown in this case with pigs from 40 $\mathrm{kg}$ of body weight by eliminating unnecessary security factors in feed formulation and resting in the huge variation of individual voluntary feed intake. The allocation of values of amino acids to the phytase with factoring matrixes could confound diets calculation and possibly lead to loss of precision in the punctual satisfaction of requirements. In short: the release of nutrients by the action of exogenous enzymes does not result in increases in the productivity of animals when these nutrients are supplied to the requirement or exceed it.

End of english version 
los animales cuando estos nutrientes se proveen al requerimiento o lo rebasan.

\section{LITERATURA CITADA}

1. Adeola O, Lawrence BV, Sutton AL, Cline TR. Phytaseinduce changes in mineral utilization in zinc-supplemented diets for pigs. J Anim Sci 1995; 73:3384-3391.

2. Selle $\mathrm{PH}$, Ravindran V. Phytate-degrading enzymes in pig nutrition. Livestock Sci 2008; 113:99-122.

3. Shelton JL, Southern LL, Binder TD, Persica MA, Braun J, Cousins B, McKnight, F. Effect of microbial phytase on energy availability, and lipid and protein deposition in growing swine. J Anim Sci 2003;81:2053-2062.

4. Johnston SL, Williams SB, Southern LL, Binder TD, Bunting LD, Matthews J O, Olcott BM. Effect of phytase addition and dietary calcium and phosphorus levels on plasma metabolites and ileal and total-tract nutrient digestibility in pigs. J Anim Sci 2004; 82: 705-714.

5. Radcliffe JS, Pleasant RS, Kornegay ET. Estimating equivalency values of microbial phytase for amino acids in growing and finishing pigs fitted with steered ileo-cecal valve cannulas. J Anim Sci 2006;84:1119-1129.

6. Guggenbuhl $P$, Waché $Y$, Simoes Nunes $C$, Fru F. Effects of a 6-phytase on the apparent ileal digestibility of minerals and amino acids in ileorectal anastomosed pigs fed on a corn-soybean meal-barley diets. J Anim Sci 2012;90:182184

7. Augspurger NR, Baker DH. High dietary phytase levels maximize phytate-phosphorus utilization but do not affect protein utilization in chicks fed phosphorus- or amino acidsdeficient diets. J Anim Sci 2004;82:1100-1107.

8. Pomar C, Gagné F, Matte JJ, Barnett G, J ondreville C. The effect of microbial phytase on true and apparent ileal amino acid digestibilities in growing-finishing pigs. J Anim Sci 2008; 86: 1598-1608.

9. Sands JS, Ragland D, Dilger RN, Adeola O. Responses of pigs to Aspergillus niger phytase supplementation of lowprotein or hight-phytin diets. J Anim Sci 2009;87:25812589.

10. Adeola O, Sands JS. Does supplemental dietary microbial phytase improve amino acids utilization? A perspective that it does not. J Anim Sci 2003;81:E78-E85.

11. Sauvant D, Perez JM, Tran G. Tables INRA-AFZ de composition et de valeur nutritive des matières premières destinées aux animaux d'élevage: 2ème édition. ISBN 2738011586, Versailles: INRA Editions; 2004.

12. Van Kempen TATG, Kim IB, Jansman AJ M, Vertegen MWA, Hancock JD, Lee DJ, et al. Regional processor variation in the ileal digestible amino acid content of soybean meal measured in growing swine. J Anim Sci 2002;80:429-439.
13. Bertolo RF, Moehn S, Pencharz PB, Ball RO. Estimate of the variability of the lysine requirement of growing pigs using the indicator amino acid oxidation technique. J Anim Sci 2005; 83:2535-2542.

14. Spindler HK, Mosenthin R, Eklund M. Evaluation through literature data on standardized ileal digestibility and basal ileal endogenous loss of amino acids associated with barley in pigs. Animal 2014. doi:10.1017/S1751731114001438.

15. Mosnier E, van der Werf HMG, Boissy J, Dourmad JY. Evaluation of the environmental implications of the incorporation of feed-use amino acids in the manufacturing of pig and broiler feeds using Life Cycle Assessment. Animal 2011; 5(12): 1972-1983.

16. Noblet J, Fortune H, Shi XS, Dubois JS. Prediction of net energy value of feeds for growing pigs. J Anim Sci 1994; 72:344-354.

17. Quiniou N, Noblet J. Effect of the dietary net energy concentration on feed intake and performance of growingfinishing pigs housed individually. J Anim Sci 2012; 90:43624372.

18. NRC. Nutrient Requirement of Swine. National Research Council. 11th ed. Washington, DC, USA: Natl. Acad. Press; 2012.

19. NRC. Nutrient Requirement of Swine. National Research Council. $10^{\text {th }}$ ed. Washington, DC, USA: Natl. Acad. Press; 1998.

20. Balderrama V, Pérez-Alvarado A, Mariscal G, Castañeda E, Braña D, Cervantes J, Cuarón J. Growth performance consequences of low phosphorus intake: prevention of the deficiency by and inorganic source or a phytase and recovery after depletion [abstract]. Proc 23rd Inter Pig Vet Soc 2014(1): 284

21. Létourneau-Montminy MP, Lovatto PA, Pomar C. Apparent total tract digestibility of dietary calcium and phosphorus and their efficiency in bone mineral retention are affected by body mineral status in growing pigs. J Anim Sci [published ahead of print July 23, 2014], doi:10.2527/jas.2013-7320.

22. AOAC. Official Methods of Analysis. 15th ed. Association of Oficial Analytical Chemist, Arlington, VA, USA: Association of Official Analytical Chemist. 1990.

23. Cisneros F, Ellis M, Miller KD, Novakofski J, Wilson ER, McKeith FK. Comparison of transverse and longitudinal realtime ultrasound scan for prediction of lean cut yields and fat-free lean content in live pigs. J Anim Sci 1996; 74:25662576.

24. Schinckel AP, Mahan DC, Wiseman TG, Einstein ME. Growth of protein, moisture, lipid, and ash of two genetic lines of barrows and gilts from twenty to one hundred twenty-five kilograms of body weight. J Anim Sci 2008;86:460-471.

25. Braña DV, Rojo-Gómez GA, Ellis M, Cuarón JA. Effect of gender (gilt and surgically and immunocastrated male) and ractopamine hydrochloride supplementation on growth performance, carcass, and pork quality characteristics of finishing pigs under commercial conditions. J Anim Sci 2013; 91:5894-5904. 